\title{
Serum Ferritin and Iron Studies - Laboratory Reporting and Clinical Application in Primary Care
}

\author{
Catherine Ogilvie and Edward Fitzsimons \\ Department of Haematology, Gartnavel General Hospital, Glasgow, \\ UK
}

\section{Introduction}

In the primary care setting blood samples are frequently taken, following clinical assessment, in order to determine a patient's iron status. This chapter will describe the laboratory tests used to assess iron status and explain interpretation of results with respect to both iron deficiency and iron overload.

Reduced serum ferritin values confirm iron deficiency and are hugely helpful in the investigation of patients with anaemia. It has however, also been shown that elevated serum ferritin is a common finding in the primary care population (Ogilvie et al, 2010) and that General Practioners (GPs) may require more guidance from Haematologists in the management of patients with raised serum ferritin levels. This will be explained and discussed with the aim of ultimately improving the diagnosis of serious underlying conditions including Hereditary Haemochromatosis (HHC).

\section{Laboratory tests}

Laboratory tests assessing body iron status are performed in both the Haematology and Biochemistry departments. Serum ferritin and iron studies are most commonly requested.

\subsection{Serum ferritin}

In simple terms ferritin can be described as the intracellular protein which safely stores excess iron. Tiny amounts of ferritin can be detected in serum and this serum ferritin is the most frequently measured surrogate for body iron stores. The normal range for serum ferritin is generally regarded as $15-300 \mu \mathrm{g} / 1$. There is no known physiological role for serum ferritin but the results of quantitative phlebotomy studies have shown that $1 \mu \mathrm{g} / 1$ of ferritin in serum is approximately equivalent to $8 \mathrm{mg}$ of stored reticuloendothelial system body iron. (Worwood, 1982).

Serum ferritin shows an acute phase response and can be elevated in a variety of inflammatory, metabolic, hepatic and neoplastic disorders. This can make it difficult to recognise iron deficiency in patients with inflammatory disorders as such disorders can 
cause serum ferritin to be elevated to levels inappropriate to the reticuloendothelial iron store.

There are however also well recognised conditions that lead to gross inappropriate elevation of serum ferritin; hepatitis, juvenile Stills disease and disseminated malignancy.

We know that total body iron content is $4 \mathrm{~g}$, with a daily requirement of only 1-2mg of iron. Body iron content is regulated by complex controls over iron absorption in the upper small bowel. The average Western diet provides $15-20 \mathrm{mg}$ of iron each day which is far in excess of the body requirement of $1-2 \mathrm{mg}$ iron per day. There are no regulatory pathways to eliminate iron from the body and losses occur only through shedding of cells in the GI tract, skin desquamation, pregnancy and menstrual loss.

Around $3 \mathrm{~g}$ of total body iron is present in mature or developing red blood cells. In the developing red cells, the erythroblasts, iron (Fe3+) is converted to iron (Fe2+) and is then combined with protoporphyrin to form haem. Haem is then combined with 2 alpha globin and 2 beta globin chains to form haemoglobin.

The reticuloendothelial system is the main storage site of iron with approximately $0.5 \mathrm{~g}$ of iron being found in macrophages. The reticuloendothelial system acquires its storage iron from the ingestion of effete red blood cells (lifespan 120 days) whereas other tissues accept iron from transferrin via transferrin receptors on the cell surface. Iron is found in all tissues but particularly as myoglobin in muscle, in hepatocytes and in many essential enzymes. Iron based enzymes can contain haem e.g. cytochrome P450 family, myeloperoxidase, lactoperoxidase and catalase or be non-haem iron based e.g. NADH dehydrogenase and the lipoxygenases.

\subsection{Iron sudies}

Iron studies in most laboratories include serum iron levels, serum transferrin or total iron binding capacity (TIBC), and transferrin saturation. Total iron binding capacity is a measurement of the maximum amount of iron that can be carried. It is therefore an indirect measurement of transferrin.

The most useful test in assessing iron supply to the tissues is transferrin saturation. Transferrin is a glycoprotein synthesised in the liver and is responsible for the transportation of iron (Fe3+) in serum. This glycoprotein has 2 iron binding domains and is normally $30 \%$ saturated with iron. In iron deficiency, reduced transferrin saturation leads to iron deprivation for erythroblasts. In iron overload raised transferrin saturation leads to parenchymal iron overload.

In iron deficiency anaemia the serum iron level falls. As a result the liver is stimulated to synthesise more transferrin and the transferrin saturation falls (usually $<15 \%$ ). In Hereditary Haemochromatosis (HHC), a condition characterised by iron overload, iron levels rise, transferrin synthesis is reduced and transferrin saturation may reach $100 \%$.

Serum iron concentration is a measurement of circulating iron $\left(\mathrm{Fe}^{3+}\right)$ bound to transferrin. Only $0.1 \%$ of total body iron is bound to transferrin at any one time. In addition, the transferrin iron pool turns over 10-20 times each day which is reflected in varying serum iron levels. Serum iron levels can fluctuate throughout the day so that measurement of serum iron concentration alone provides little useful clinical information. 


\section{Normal Iron Homeostasis}

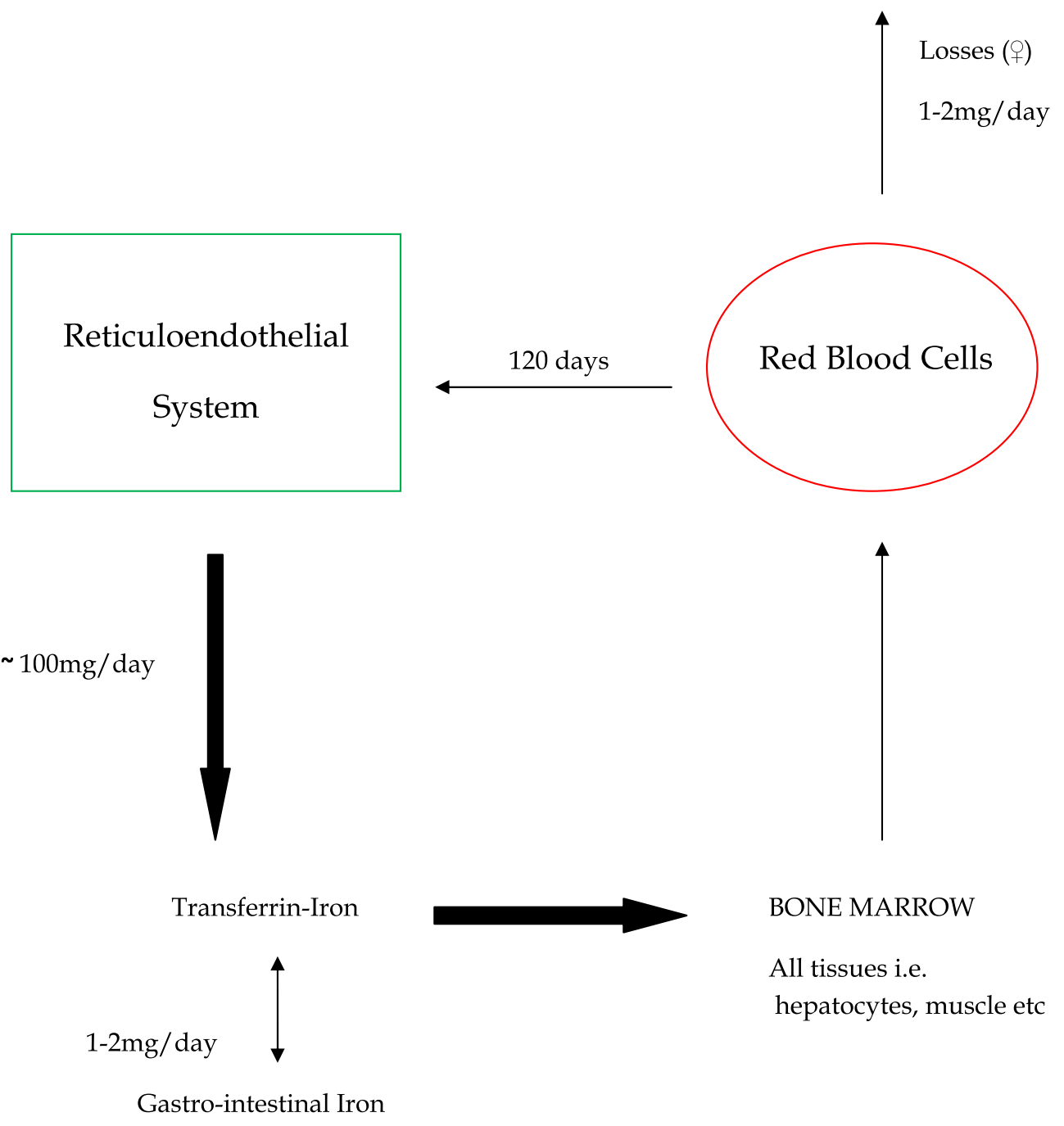

Fig. 1. Normal Iron Homeostasis

\section{Iron deficiency}

The majority of laboratory requests for serum ferritin and iron studies are made following a clinical suspicion of possible iron deficiency. As iron deficiency develops transferrin saturation falls to $<15 \%$ and serum ferritin levels are reduced. Thereafter full blood count (FBC) parameters become abnormal, with reduced haemoglobin, low mean corpuscular 
haemoglobin $(\mathrm{MCH})$ and low mean corpuscular volume (MCV) i.e. a hypochromic microcytic anaemia.

In the developed world IDA is most commonly seen in young women as a result of menstruation and pregnancies (each pregnancy costs the mother $500 \mathrm{mg}$ of iron through iron transfer to foetus and blood loss at delivery). However IDA also occurs in 2-5\% of males and post-menopausal females. Blood loss from the gastro-intestinal (GI) tract is the most common cause. The British Society of Gastroenterology recommends upper and lower GI investigations and to consider screening for coeliac disease. (Goddard et al, 2011)

Specific issues are relevant in primary care. General Practioners often prescribe iron supplements and should be aware of the different elemental iron content of each preparation. For example, ferrous fumarate $210 \mathrm{mg}$ contains $68 \mathrm{mg}$ iron whereas ferrous gluconate $300 \mathrm{mg}$ contains $35 \mathrm{mg}$ iron. The amount of elemental iron often influences tolerability. Main side effects are gastrointestinal e.g. nausea and constipation. When such side effects lead to non compliance we suggest changing to a preparation containing less elemental iron. Patients who continue to have difficulty or cannot tolerate tablets may benefit from a syrup preparation. Syrups enable a smaller dose of elemental iron to be given. Parental infusions of iron should be reserved for those few patients who despite lower doses remain intolerant of oral iron. Iron infusion is also a treatment option for non compliant patients with significant anaemia. These patients should be referred and managed in secondary care.

Recurrent IDA can be difficult to manage. In a male or post menopausal female patient with normal upper and lower GI endoscopies it can be difficult to determine when repeat investigations or further procedures e.g small bowel examination are needed. In these cases however reassurance must be taken from the endoscopic exclusion of GI malignancy as the cause of IDA. Clinical assessment, severity of anaemia, speed of recurrence and response to iron supplements can be helpful. Any patients causing ongoing concern should be referred to secondary care.

\section{Anaemia of Chronic Disease (ACD)}

Anaemia of chronic disease (ACD) is used to describe the anaemia that develops in response to chronic illness despite normal haematinic levels (normal B12, folate and ferritin) and without blood loss. Serum iron falls but unlike IDA the transferrin level also falls (Fitzsimons et al, 2002). There are 3 main causes of ACD; inflammatory, infectious or malignant disorders. ACD can cause either a normochromic normocytic anaemia or a hypochromic microcytic anaemia. The latter may be difficult to distinguish from iron deficiency anaemia as the serum ferritin level may be elevated by the acute phase response. However, in most cases of ACD the level of storage iron remains the most important factor controlling serum ferritin concentration. Serum ferritin levels $>100 \mu \mathrm{g} / \mathrm{l}$ are thought to indicate iron replete status and the presence of storage iron in inflammatory states - so excluding iron deficiency (Witte 1991). Measurement of other acute phase proteins e.g. Creactive protein (CRP), erythrocyte sedimentation rate (ESR) and good clinical history and examination can help to distinguish ACD from IDA. Measurement of serum soluble transferring receptor (sTfR) can reliably distinguish IDA from ACD but this assay is seldom available from UK laboratories. 
In ACD treatment of the underlying condition is the most important factor in correcting the anaemia. Many inflammatory conditions are managed in secondary or tertiary care and the use of monoclonal antibody therapy to inhibit cytokine response e.g. Infliximab in rheumatoid arthritis and inflammatory bowel disease has greatly influenced the course of such diseases and their associated chronic anaemias.

General Practioners however may be required to manage chronic dysproteinaemic anaemia. This is often seen in patients with polymyalgia rheumatica (PMR) or temporal arteritis (TA). It can however be found without features of either PMR or TA. The anaemia is often hypochromic, microcytic and associated with elevated ESR $>100 \mathrm{~mm} / \mathrm{h}$, raised globulins without paraprotein. The anaemia is extremely sensitive to steroid although a small maintenance dose of prednisolone (ie $5 \mathrm{mg}$ daily) may be required longterm to maintain a normal haemoglobin. . (Fitzsimons and Brock, 2001)

\section{Summary of laboratory findings}

The table below summarises laboratory findings in the normal state, in iron deficiency anaemia, hereditary haemochromatosis and anaemia of chronic disease.

\begin{tabular}{|l|l|l|l|l|}
\hline & Normal & $\begin{array}{l}\text { Iron deficiency } \\
\text { Anaemia }\end{array}$ & $\begin{array}{l}\text { Hereditary } \\
\text { Haemochromatosis }\end{array}$ & $\begin{array}{l}\text { Anaemia of } \\
\text { Chronic } \\
\text { Disease }\end{array}$ \\
\hline Serum Ferritin & $\begin{array}{l}(15-300 \mu \mathrm{g} / \mathrm{l}) \\
\text { Transferrin } \\
\text { Saturation }\end{array}$ & $\downarrow$ & $\uparrow$ & $\leftrightarrow / \uparrow$ \\
\hline Serum Iron & $(15-30 \%)$ & $\downarrow$ & $\uparrow$ & $\downarrow$ \\
\hline
\end{tabular}

Table 1. Summary of Laboratory Findings

\section{Hereditary Haemochromatosis}

Hereditary Haemochromatosis (HHC) is a particularly important diagnosis to be considered in the further investigation of patients with unexplained elevated serum ferritin level.

\subsection{Genetics of Hereditary Haemochromatosis}

Hereditary Haemochromatosis is inherited as an autosomal recessive disorder and is one of the most common single gene disorders in the North European population. In the United Kingdom (UK) it is estimated that approximately 250,000 people have the genetic predisposition yet only some 5000 people have been formerly diagnosed with HHC.

The human haemochromatosis protein is named HFE - High iron (Fe). The mutation most commonly associated with $\mathrm{HHC}$ is the $\mathrm{C} 282 \mathrm{Y}$ mutation. In the UK $8-12 \%$ of the population is heterozygous for C282Y (ie. carriers of HHC) and more than $90 \%$ of HHC cases are HFE homozygous for C282Y. Approximately $6 \%$ of cases are compound heterozygote for 
C282Y/H63D. The cellular mechanisms by which HFE leads to increased iron gastrointestinal iron absorption and raised serum iron levels are not understood.

\subsection{Clinical features and treatment}

As transferrin saturation rises to $>50 \%$ tissue iron uptake increases and can lead to end organ damage; hepatic cirrhosis (and hepatocellular carcinoma), cardiomyopathy, pituitary and thyroid gland impairment, diabetes mellitus, skin pigmentation (bronze diabetes), hypogonadism and arthropathy. The presenting features can therefore be varied and diagnosis delayed until iron stores are greatly increased (20-30g) and tissue damage has occurred. Disease is seldom evident at age $<30$ yrs. Early diagnosis and damage prevention is essential. All morbidities, once the condition is recognised, can be either prevented or lessened with simple treatment - venesection.

Phlebotomy is used to treat HHC with up to one unit of blood $(500 \mathrm{ml}=250 \mathrm{mg}$ iron) being venesected weekly. Serum ferritin and transferrin saturation are used to guide frequency of venesection (BCSH, 2002). The aim is to normalise iron stores - ferritin and transferrin saturation - and prevent end organ damage. Once this is achieved maintenance venesection should be tailored to maintain serum ferritin level $<50 \mu \mathrm{g} / 1$ and transferrin saturation $<50 \%$. It should be noted that in some patients transferrin saturations can remain $>50 \%$ despite serum ferritin $<50 \mu \mathrm{g} / \mathrm{l}$. We would suggest that these patients require more aggressive venesection programmes.

\subsection{Laboratory findings}

Biochemically HHC is characterised by an elevated (often grossly elevated) serum ferritin level, raised serum iron and increased transferrin saturation.

Serum ferritin is highly sensitive to iron overload in HHC (BCSH guideline 2002). A high serum ferritin level however has low specificity for HHC as the majority of patients with raised ferritin levels do not have HHC. Careful clinical history taking and examination are therefore important. Subsequent appropriate investigations and interpretation of other acute phase proteins should enable prompt diagnosis of other conditions e.g. inflammatory or neoplastic conditions. It is important to note that, even when HHC has been excluded, a serum ferritin level $>1000 \mu \mathrm{g} / \mathrm{l}$ is often indicative of serious underlying pathology e.g disseminated malignancy, liver disease of any aetiology, inflammatory arthropathy.

Serum ferritin is often elevated in hepatic cirrhosis of any aetiology. This is a major confounding factor in the use of serum ferritin in the diagnosis of HHC. The liver reticuloendothelial cells contain storage iron. The hepatocytes are a rich source of iron containing enzymes and ferritin. Any process which damages liver cells will release hepatic ferritin into the serum, causing an elevated level. It is also possible that liver impairment may interfere with the clearance of ferritin from the circulation and so further contribute to elevated levels.

The combination of a raised serum ferritin level and increased transferrin saturation however is a powerful predictor for the clinical condition of HHC. A transferrin saturation $>50 \%$ together with a raised serum ferritin level is predictive of homozygosity for the C282Y mutation of the HFE gene in $90 \%$ of males and $75 \%$ of females (Gordeuk et al 2008). 


\subsection{Genotype versus phenotype}

Assessment of body iron stores is of upmost importance in the diagnosis of HHC. Although the genetic predisposition to HHC is common, the disease penetrance is low i.e. not all people with the genetic predisposition for HHC go on to develop any evidence of iron overload or clinical disease.

Approximately 1 in 300 people in the UK are homozygous for the C282Y mutation. However, only $38-50 \%$ of C282Y homozygotes will develop laboratory evidence of iron overload and 10-33\% will develop any end organ damage (Whitlock et al 2006). The other factors influencing disease penetrance are not yet clearly established. Consequently, the UK National Screening Committee does not recommend molecular screening for HFE C282Y mutation in the asymptomatic population.

We would recommend transferrin saturation as initial further investigation of elevated serum ferritin level. Clinical history and examination remain important as do other routine targeted laboratory investigations e.g liver enzymes. HFE genotyping is likely to be appropriate in patients with raised serum ferritin values when the transferrin saturation level $\geq 50 \%$.

\subsection{Family screening}

Family screening is required for relatives of a patient with HHC.

Such screening is important primarily to identify further homozygotes and to ensure prevention of iron overload and tissue damage. Secondly, screening allows reassurance of heterozygotes and those with a normal genotype.

Laboratory screening tests should comprise assessment of iron stores (serum ferritin, serum iron and transferrin saturation) and HFE genotyping. Siblings and offspring of an affected family member should be screened. Given the high frequency of heterozygotes in the population $(\sim 10 \%$ in the UK), we would suggest that partners of known homozygous patients and heterozygous carriers should also be screened to identify the potential risk to any offspring. If both parents are heterozygous each child will have a 1 in 4 chance of being homozygous. If one parent is homozygous and the other heterozygous the risk of any child being homozygous is 1 in 2 .

Family members should be counselled as to the mode of inheritance of HHC, the importance of early diagnosis and the effectiveness and ease of treatment i.e iron overload and tissue damage can be prevented by simple venesection.

The cartoon below (Figure 2) schematically demonstrates transferrin saturation; the transferrin protein $(\mathrm{Y})$ combining with iron ( ). Two atoms of ferric iron bind to each transferrin molecule.

\section{Elevated serum ferritin levels in primary care}

Primary care physicians are often familiar with low serum ferritin values and the investigation and treatment of iron deficiency anaemia. However, a need for guidance in further investigation of elevated serum ferritin has recently been identified (Ogilvie et al, 2010). 


\section{Anaemia of Chronic Disease}

Fig. 2. The transferrin protein and iron binding.

\subsection{West of Scotland experience}

Greater Glasgow and Clyde (GG\&C) is located on the West coast of Scotland and is the largest single Health Board in Scotland with a population of 1.4 million. During 2009 a total of 158,495 serum ferritin measurements were performed. Approximately $50 \%$ of samples were referred from primary care and $50 \%$ of these from patients $>30$ years of age. We surveyed all serum ferritin results obtained in our hospital from patients aged $>30 \mathrm{yrs}$ in primary care during a 6 month period. All requests were initiated by the General Practioner and included 3029 females (73\%) and 1141 males (27\%).

Only $8 \%$ of women aged $30-50$ years had serum ferritin levels $>100 \mu \mathrm{g} / \mathrm{l}$. In this age group IDA is the most frequent abnormalilty of iron metabolism reflecting the effects of menstruation and child birth. Mean serum ferritin levels rose progressively with female age. Serum ferritin levels $>200 \mu \mathrm{g} / \mathrm{l}$ were seen in $7.5 \%$ of women aged $50-59$ years, $13 \%$ of women aged $60-69$ years and $17 \%$ of women aged over 70 years. In contrast, irrespective of age, $17 \%$ of males over 30 years had serum ferritin levels $>300 \mu \mathrm{g} / 1$. (Tables 2 and 3).

A total of 59 patients had grossly elevated serum ferritin levels $>1000 \mu \mathrm{g} / 1$ (30 males, 29 females). A review of the electronic individual patient case record was performed. In 27 cases the grossly elevated serum ferritin level had been noted and an explanation given. 1 patient was found to have Hereditary Haemochromatosis (HHC); 18 patients had non $\mathrm{HHC}$ liver disease (alcoholic liver disease, hepatitis $C$, hepatic steatosis). 10 of these 18 patients had HHC excluded (confirmed HFE genotype negative); 7 patients had disseminated malignancy. 1 patient had iron overload secondary to frequent packed red cell transfusion required due to prosthetic cardiac valve haemolysis. 
However, more than half of patients $(n=32)$ with grossly elevated serum ferritin levels were neither investigated nor referred to secondary care. The investigation of patients with serum ferritin values $>1000 \mu \mathrm{g} / 1$ is particularly important as it has been shown that the risk of cirrhosis in HHC occurs only with serum ferritin levels $>1000 \mu \mathrm{g} / \mathrm{l}$. HHC is an easily treatable condition once identified. Iron depletion via venesection $(500 \mathrm{mls}$ whole blood $=$ 250mg iron) can prevent end organ damage e.g. liver cirrhosis, diabetes. In addition, given the proportion of patients not further investigated, it is clear that more guidance to GPs on further management of these patients is needed.

\begin{tabular}{|c|c|c|c|c|}
\hline Male Patients & $\begin{array}{c}\text { Ferritin } \\
>100 \mu \mathrm{g} / 1\end{array}$ & $>200 \mu \mathrm{g} / 1$ & $300-1000 \mu \mathrm{g} / 1$ & $>1000 \mu \mathrm{g} / \mathrm{l}$ \\
\hline $\begin{array}{c}\text { Age } \\
\text { 30-49yrs }\end{array}$ & $153(58 \%)$ & $80(30 \%)$ & $47(18 \%)$ & $11(4 \%)$ \\
\hline $50-69 \mathrm{yrs}$ & $209(53 \%)$ & $118(31 \%)$ & $66(17 \%)$ & $9(2 \%)$ \\
\hline $70 y r s+$ & $245(50 \%)$ & $130(26 \%)$ & $84(17 \%)$ & $11(2 \%)$ \\
\hline
\end{tabular}

Table 2. Ferritin values in male patients $>30 y$ rs in Primary Care.

\begin{tabular}{|c|c|c|c|c|}
\hline $\begin{array}{c}\text { Female } \\
\text { Patients }\end{array}$ & $\begin{array}{c}\text { Ferritin } \\
>100 \mu \mathrm{g} / 1\end{array}$ & $>200 \mu \mathrm{g} / \mathrm{l}$ & $300-1000 \mu \mathrm{g} / \mathrm{l}$ & $>1000 \mu \mathrm{g} / 1$ \\
\hline $\begin{array}{c}\text { Age } \\
\text { 30-49yrs }\end{array}$ & $101(8 \%)$ & $40(3 \%)$ & $15(1.5 \%)$ & $3(0.3 \%)$ \\
\hline $50-69 \mathrm{yrs}$ & $215(28 \%)$ & $77(10 \%)$ & $34(4 \%)$ & $8(1.0 \%)$ \\
$50-59 y r s$ & $92(22 \%)$ & $31(7.5 \%)$ & $12(3 \%)$ & $5(1.0 \%)$ \\
$60-69 y r s$ & $123(35 \%)$ & $46(13 \%)$ & $22(6 \%)$ & $3(1.0 \%)$ \\
\hline $70 \mathrm{yrs}+$ & $452(38 \%)$ & $206(17 \%)$ & $97(8 \%)$ & $16(1.3 \%)$ \\
\hline
\end{tabular}

Table 3. Ferritin values in female patients $>30 \mathrm{yrs}$ in Primary Care

\subsection{Current reporting practice}

A survey of Scottish laboratories has shown that it is routine practice only to report serum ferritin levels $>1000 \mu \mathrm{g} / \mathrm{l}$ as 'grossly elevated'. No further advice is currently provided. Given the above findings it would seem appropriate for laboratory reports to recommend hospital referral for all patients with serum ferritin level $>1000 \mu g / 1$, unless otherwise explained. It is as yet unclear as how best to advise General Practioners for patients with ferritin values between 300-1000 $\mu \mathrm{g} / \mathrm{l}$. We would suggest further assessment of body iron stores with measurement of transferrin saturation. High transferrin saturation would then warrant further molecular screening for HHC. With the support of the Chief Scientist Office for Scotland we are now trying to establish an algorithm for the Scottish population based on age, sex, serum ferritin and transferrin saturation that might trigger a request for molecular screening for HHC.

\section{Conclusion}

We have discussed the use of laboratory tests to assess iron status in the primary care population. General Practioners frequently request serum ferritin levels and iron studies. 
Often these tests are used to assess iron status when there is clinical suspicion of iron deficiency. General Practioners are familiar with the interpretation of these tests in iron deficiency (a reduced ferritin is irrefutable evidence of iron deficiency) but require more guidance when the serum ferritin level is elevated and iron overload is possible. Ferritin is an acute phase protein and can be elevated to levels inappropriately high for the degree of reticuloendothelial iron stores by infectious, neoplastic or inflammatory conditions. Even when HHC has been excluded a serum ferritin level $>1000 \mu \mathrm{g} / 1$ most often indicates significant underlying pathology and must be further investigated.

HHC is an autosomal recessive disorder and is one of the most common single gene disorders in the North European population. The morbidities associated are serious and preventable. Timely diagnosis is therefore important and family screening of HHC patients is essential. Molecular screening of at risk but asymptomatic population (i.e Celts) is not recommended by the UK National Screening Committee as disease penetrance is $<50 \%$. Clear guidance is required to investigate patients with unexplained raised serum ferritin values. Elevation of serum ferritin level should prompt measurement of transferrin saturation and thereafter HFE genotype if saturation exceeds $50 \%$.

\section{References}

BCSH; British Committee for Standards in Haematology (2002). Dooley J and Worwood M. Guidelines for diagnosis and therapy of genetic haemochromatosis.

Fitzsimons EJ, Brock JH. (2001) The anaemia of chronic disease. BMJ;322:811-12.

Fitzsimons EJ, Houston T, Munro R, Sturrock RD, Speekenbrink AB, Brock LH (2002). Erythroblast iron metabolism and serum soluble transferrin receptor values in the anaemia of rheumatoid arthritis. Arth Rh. 15;47(2) 166-71.

Goddard AF, James MW, McIntyre AS, Scott BB on behalf of the British Society of Gastroenterology. Guidelines for the management of iron deficiency anaemia. Gut. 2011; 60:1309-1316.

Gordeuk VR, Reboussin DM, McLaren CE, Barton JC, Acton RT, McLaren GD, Harris EL, Reiss JA, Adams PC, Speechley M, Phatak PD, Sholinsky P, Eckfeldt JH, Chen WP, Passmore L, Dawkins FW (2008). Serum ferritin concentrations and body iron stores in a multiethnic primary care population. American Journal of Haematology.83;618-626.

Ogilvie C, Fitzsimons K, Fitzsimons E.(2010). Serum ferritin values in primary care: are high values overlooked. J Clin Pathol. 2010;63:1124-1126.

Whitlock EP, Garlitz BA, Harris EL (2006). Screening for hereditary haemochromatosis; a systematic review of the US preventive series Task Force. Annals Int Medicine.145;209-223.

Witte DL (1991). Can serum ferritin be effectively interpretated in the presence of the acute phase response. Clinical Chemistry.37;484-485.

Worwood (1982). Ferritin in human tissues and serum. Clinics in Haematology. 11; 275-307. 


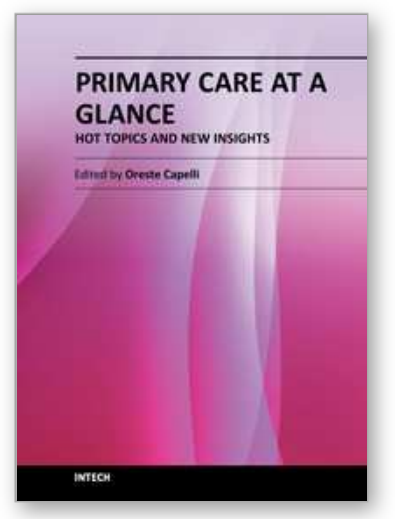

\author{
Primary Care at a Glance - Hot Topics and New Insights \\ Edited by Dr. Oreste Capelli
}

ISBN 978-953-51-0539-8

Hard cover, 446 pages

Publisher InTech

Published online 27, April, 2012

Published in print edition April, 2012

"Both among scientists and clinical practitioners, some find it easier to rely upon trivial explanations, while others never stop looking for answers". With these surprising words, Augusto Murri, an Italian master in clinical medicine, reminds us that medical practice should be a continuous journey towards knowledge and the quality of care. The book brings together contributions by over 50 authors from many countries, all around the world, from Europe to Africa, from Asia to Australia, from North to South America. Different cultures are presented together, from those with advanced technologies to those of intangible spirituality, but they are all connected by five professional attributes, that in the 1978 the Institute of Medicine (IOM) 1 stated as essentials of practicing good Primary Care: accessibility, comprehensiveness, coordination, continuity and accountability. The content of the book is organized according to these 5 attributes, to give the reader an international overview of hot topics and new insights in Primary Care, all around the world.

\title{
How to reference
}

In order to correctly reference this scholarly work, feel free to copy and paste the following:

Catherine Ogilvie and Edward Fitzsimons (2012). Serum Ferritin and Iron Studies - Laboratory Reporting and Clinical Application in Primary Care, Primary Care at a Glance - Hot Topics and New Insights, Dr. Oreste Capelli (Ed.), ISBN: 978-953-51-0539-8, InTech, Available from: http://www.intechopen.com/books/primarycare-at-a-glance-hot-topics-and-new-insights/serum-ferritin-and-iron-studies-laboratory-reporting-and-clinicalapplication-in-primary-care

\section{INTECH}

open science | open minds

\section{InTech Europe}

University Campus STeP Ri

Slavka Krautzeka 83/A

51000 Rijeka, Croatia

Phone: +385 (51) 770447

Fax: +385 (51) 686166

www.intechopen.com

\section{InTech China}

Unit 405, Office Block, Hotel Equatorial Shanghai

No.65, Yan An Road (West), Shanghai, 200040, China

中国上海市延安西路65号上海国际贵都大饭店办公楼 405 单元

Phone: +86-21-62489820

Fax: $+86-21-62489821$ 
(C) 2012 The Author(s). Licensee IntechOpen. This is an open access article distributed under the terms of the Creative Commons Attribution 3.0 License, which permits unrestricted use, distribution, and reproduction in any medium, provided the original work is properly cited. 